\title{
SOCIO-ENVIRONMENTAL RIGHTS AND THE RIDDLE OF HISTORY
}

\author{
DIREITOS SOCIOAMBIENTAIS E O ENIGMA DA HISTÓRIA
}

Bruce Gilbert*

\begin{abstract}
Broadly speaking, this paper is about the relationship of the human rights tradition to substantive issues of social justice, including class exploitation and environmental destruction. These themes I take to be of global concern, but I will examine them today as they arise from conflicts and struggles situated in Brazil. The key to the argument is to show that the human rights tradition recognizes necessary features of self-determination, and that claims for socio-environmental rights in Brazil and elsewhere derive their legitimacy from the same kind of argument that justifies individual rights, such as the 1948 United Nations Declaration, and collective rights, such as the International Covenant on Economic, Social and Cultural Rights of 1966 and the United Nations Declaration of the Rights of Indigenous Peoples of 2007. That is, I will try to show that individual, collective and socio-environmental rights are each necessary conditions but, on their own, insufficient conditions for the possibility of selfdetermination. The need for such rights emerges in the history of the struggle for justice. This this paper will also defend the claim that the universality of rights necessarily emerges from the historicity of social life and solves what Marx calls the "riddle of history."

Keywords : Socio-enviromental rights; riddle of history.
\end{abstract}

Resumo: De um modo geral, este artigo trata da relação da tradição dos direitos humanos com questões substantivas de justiça social, incluindo a exploração de classes e a destruição ambiental. Esses temas são de interesse global, mas vou examiná-los hoje, pois eles surgem de conflitos e lutas no Brasil. A chave do argumento é mostrar que a tradição dos direitos humanos reconhece as características necessárias à autodeterminação, e que as reivindicações por direitos socioambientais no Brasil e em outros lugares derivam sua legitimidade do mesmo tipo de argumento que justifica os

\footnotetext{
* Bruce Gilbert has a Ph. D from the Department of Philosophy at the Pennsylvania State University (B.A. History, Toronto; Diploma in Education and Pastoral Care, Centre for Christian Studies; M.A. Religious Studies, McGill). His recent book, The Vitality of Contradiction: Hegel, Politics and the Dialectic of Liberal-Capitalism (McGill-Queen's University Press, 2014), won the Biennial Book Prize of the Canadian Philosophical Association. It articulates the philosophical arguments for a society that is politically but also economically and culturally democratic. He has a cross appointment at Bishop's, teaching in both the Department of Philosophy and the Liberal Arts Program. Dr. Gilbert's research, most broadly speaking, engages dialectical philosophy in the spheres of ethics, society, politics, ecology and religion. If dialectic names the process by which humanity learns, then freedom is not merely choice, but is rather our capacity to develop increasingly sophisticated forms of relationship with each other and our environment. Dr. Gilbert also engages in empirical research on this topic, focusing on social movements in Brazil, especially on the Movement of Landless Rural Workers of Brazil (MST), a large and very successful social movement which occupies under-utilized land in order to create self-sufficient farming cooperatives. E-mail: bgilbert@ubishops.ca.
} 
direitos individuais, como o Declaração das Nações Unidas de 1948, e direitos coletivos, como o Pacto Internacional sobre Direitos Econômicos, Sociais e Culturais de 1966 e a Declaração dos Direitos dos Povos Indígenas das Nações Unidas de 2007. Ou seja, tentarei mostrar que os direitos individuais, coletivos e Direitos socioambientais são, cada um, condições necessárias, mas, por si só, condições insuficientes para a possibilidade de autodeterminação. A necessidade de tais direitos surge na história da luta pela justiça. Este artigo também defenderá a afirmação de que a universalidade dos direitos surge necessariamente da historicidade da vida social e resolve o que Marx chama de "enigma da história".

Palavras-chave: direitos socioambientais; enigma da história.

\section{CAPITALISM AND INJUSTICE}

There are two forms of injustice in capitalist societies that are essential to the argument of this paper, exploitation and systematic environmental destruction, each of which I will briefly describe before turning to a study of the key claims I will make about rights in general and socio-environmental rights in particular.

Exploitation, in Marx's technical sense of the term, is the definitive form of domination within capitalism ${ }^{1}$. Those who have exclusive control over the means of production successfully "exploit" those who lack it and who must thereby sell their labour power on the market for a wage. Wage labourers are nearly always exploited for the simple reason that they produce more value in a day then they are paid for. Marx called "surplus value" the amount of wealth created during a typical working day that exceeds the cost of "reproducing the worker"-effectively, of wages. While the worker's contract makes it seem that she is paid for each of her working hours, in fact once the amount of new value she has created exceeds the cost of her wages she is simply working for free. The surplus value created by workers forms the bulk of profit, which is accumulated by the owners of the means of production. These owners, typically stockholders, make a profit from the labour of the workers, without working themselves and thereby form a plutocratic class that has the wealth and power to dominate the economy and the state-the "1\%". Resistance to exploitation, accordingly, involves protecting those everyday people who already control the means of production (such as small farmers, some indigenous communities, etc) or, indeed, attaining it in the first place (such as land occupations by the MST, CPT, etc). An incomplete form of resistance to exploitation takes the form of diminishing its rate, such as one finds when wage-labourers successfully strike for higher pay. 
But there is another form of injustice only implied in Marx's notion of alienation articulated in the 1844 Manuscripts-human alienation from nature. Capitalist and pseudo-socialist nations (like China) alike do not even have sustainable relationships with the natural world, much less economies that embody a much deeper respect for an interdependence with nature, as one typically finds in the economies of indigenous peoples in the Americas.

While exploitation and destruction of nature often go hand in hand, there is no essential link between them. Non-exploitive agricultural cooperatives can still engage in unjust and unsustainable relationships with nature-such as when they use chemical fertilizers and pesticides, mono-culture, and so on. And it is conceivable, even if extremely uncommon, that exploitive economic units strive for and achieve sustainable relationships with nature. Portugal, for example, though still an economy based on the private property of the means of production, produces all of its electrical energy from renewable sources.

Attempts to overcome exploitation in Latin America have traditionally involved one of two strategies. First, revolutions succeeded in Cuba in 1959 and Nicaragua in 1979 but were brutally defeated in every other country. Second,

Progressive political coalitions, such as those that won elections in Guatemala in 1944 and Chile in 1970 were soon overthrown in military coups. The only alternative, it seemed, was reformist change. Enter, for example, Samuel Moyn's important book, The Last Utopia: Human Rights in History ${ }^{2}$. Given the failure of substantive change in the 1960's and 70's, progressive people, Moyn argues, have retreated to a kind of last line of defense: human rights. In other words, if substantive forms of justice are impossible, then the best we can do is retreat to human rights, a bulwark against the worst forms of injustice and manipulation. Brazilians have led the way to a third strategy, to which we will now turn.

\section{TRADITIONAL PEOPLES AND COMMUNITIES IN BRAZIL}

Social movements in Brazil, especially the Movement of Landless Rural Workers (MST), have successfully adopted a way to confront exploitation that does not prioritize attaining state power. Brazil has long had an enormous unemployed or underemployed rural population - the legacy of plantation agriculture and slavery. After abolition in 1888, most large landowners, the latifundiarios, actually found it more 
profitable to employ temporary, itinerant rural labourers than slaves, for the latter had to be fed and housed twelve months a year, and the former only hired in large numbers at harvest time. That is to say, both the rate and quantity of exploitation was often higher for plantation owners with wage labour rather than slave labour. The enormous and deeply impoverished rural class was mostly illiterate, terribly vulnerable to health afflictions and utterly marginalized from the political process. Their squalor contrasted markedly with the plentiful land and agricultural opulence of Brazil. Attempts at agrarian reform came to nothing or, as in 1964, led to a military coup-precisely ten years after the coup in Guatemala and nine years before the one in Chile. Migrating to the cities by the hundreds of thousands, this impoverished rural class soon created, filled up and overflowed the teaming favelas in and around Brazil's major cities.

In the early 1980's Christian activists inspired by liberation theology joined forces with Brazil's poor to change the situation completely. Instead of waiting in vain for a state-led agrarian reform, peasants occupied land first and then tried to get legal title to it. This strategy proved to be an enormous success. By 1984 the Movement of Landless Rural Workers of Brazil (MST) was formed and used the "occupation" strategy to form many thousands of cooperative farming communities across all of Brazil. These settlements employ a variety of kinds of cooperatives, establish their own health care and educational programs, and elect representatives to regional, state and national bodies. The state and national MST has not only created bilateral agreements with over two dozen Brazilian universities but have formed their own national school near Sao Paulo to train activists from all across Latin America.

Land occupations are an excellent example of the re-appropriation of the means of production and thus the elimination of exploitation. MST members share amongst themselves the surplus value they create. The MST strategy, in other words, has been to create islands of socialism all across Brazil. The success of this strategy should not be exaggerated - the MST still depends on various forms of support from the state - from credit to the legalization and protection of their property by the police and the judiciary, and, moreover, they still represent a very small percentage of the national population. All the same, the aggressive pursuit of self-managed and variously cooperative settlements represents a fascinating and important development in left-wing strategies for substantive forms of justice.

The MST is in an alliance with other groups of people in Brazilian context who are united under the name of "traditional peoples and communities". This refers to R. Fac. Dir. UFG, v. 42, n. 1, 145-158, jan/abr. 2018 
those peoples and communities in Brazil that (a) have a strong from of collective identity, and that (b) not only generate their means of subsistence from nature but also have an intimate connection to the land or waters upon which they live and depend. This alliance of "traditional peoples and communities" thus includes not only MST settlements, but all of Brazil's indigenous peoples, Quilombos, ribeirinhos, fishing villages along Brazil's long, tropical coastline, among others. Like the MST, other traditional peoples and communities typically have control over the means of production, are neither perpetrators nor victims of exploitation and engage in mutual and sustainable relationships with nature.

These traditional peoples and communities have allied with each other to struggle for not only for their collective (as opposed to individual) rights to selfdetermination, but also for their "socio-environmental rights". That is, since it impossible for these communities to be self-determining in a manner independent of the lands and rivers with which they are so intimately related, their rights struggles must be "socio-environmental", they must include not only a right to these lands and rivers, but that they be protected from environmental damage of all kinds.

Herein, the rights tradition goes far beyond its usual protection of individual persons, but sets up the parameters for a more radical and substantive forms of justice. Human rights, after all, seem all too often to express the forms of law and ideology that institutionalize capitalist exploitation. The right to a just wage, for example, is part of the right to free contract, and both are really just the right to be exploited; the right to private property "for everyone" really just protects the private property of the means of production by a small class of plutocrats, and so on. On the other hand, however, it is impossible for critics of this type to ignore the fact that rights talk repeatedly re-emerges as part of the discourse and aspiration of the concrete projects of liberation and selfdetermination, including those of traditional peoples and communities in Brazil. Let us now turn to a discussion of the problem of rights discourse.

\section{THE RIDDLE OF HISTORY}

In order to do so I will employ a metaphor Marx uses in the 1844 Manuscripts, the "riddle of history"3, which is really just one of the ways that Marx articulates the nature of dialectical thought and action. Indeed, as a dialectician, Marx thinks that reality is always a riddle, always enigmatic. To take this enigmatic notion of 
history seriously we must, I think, come to see rights discourse and struggle as necessarily and unavoidably ambivalent. Moreover, the practice of traditional peoples and communities in the struggle for socio-environmental rights is an exemplar of this dynamic, and thus they may also be part of the solution to the riddle of history.

Let us begin, then, with Marx and see how his philosophy embodies the ambivalence of the leftist politics to which I have briefly referred. Most evidently, the "rights of man" are for Marx the ideological and legal superstructure that enable capitalism to grow and thrive. Specifically, the institutionalization of the right to private property, while apparently universal, is really the means by which a small elite of capitalists have exclusive control of the means of production. Those who do not own the means to produce a living for themselves, as we have already seen, must sell their labour power to capitalists and have most of the new value they produce expropriated from them. Moreover, the economic, cultural and political pressure placed upon, for example, indigenous people who still do control the means not only of economic but also cultural reproduction, is enormous. In this light, the putative freedom and equality of rights hides at least three things: the stark reality of the plutocratic, capitalist state, the exploitation of the vast majority of the population, and the relentless assimilation of traditional peoples and communities. From this Marxist point of view, human rights are part of the problem. Indeed, some recent European proponents of this aspect of Marxism are Slavoj Zizek and Alain Badiou, both of whom in one way or another deride human rights as representing a kind of desperate tinkering that functions to mitigate the worst forms of capitalist abuse at a time when projects of substantive change have been abandoned. Rights attempt at best to mitigate the worst effects of capitalism while never addressing their causes. In this light, human rights are, to return to the locution of Samuel Moyn, the "last utopia", a kind of false eschatological hope for a disillusioned left.

And yet in another sense Marx unleashes this form of criticism of rights only because he fully embodies the Enlightenment aspiration for human emancipation from domination that gave rise to right discourse in the first place. Unlike Nietzsche, Marx's attitude towards Enlightenment ideals of freedom and equality is thus a very complex one. Marx seeks the true freedom of the cooperative association of producers with each other and with nature rather than the false freedom of liberal capitalism, and he seeks the true, concrete equity of the doctrine, "from each according to his or her 
abilities, to each according to his or her need"4, rather than the false abstract equality of liberalism, which obscures really existing inequality.

Indeed, this is why Marx uses terms like the "riddle of history" in the 1844 Manuscripts, and this "riddling", "enigmatic" thought is the key to understanding his, and indeed our, way through this confusion. Human rights are an example of this kind of riddle precisely in the sense that they manifest themselves both as part of the problem and as part of its solution. Though Marx himself did not put it precisely this way, the notion of the universal rights of humanity not only institutionalizes the legal and ideological structure of liberal capitalism, but also unleashes a creative imaginary that transcends them. Let us look at this somewhat more closely.

When Marx uses the expression the "riddle of history" in 1844 Manuscripts he is speaking metaphorically of the dialectical method that he learned from Hegel and, indeed, from Plato and Aristotle. Dialectic, in this context at least, is the philosophical insight that many forms of socio-economic and political life develop tensions or conflicts within themselves, from which are born more sophisticated forms of society. These "tensions", "conflicts" or "riddles" are expressed more technically by the term "contradiction". Societies, in short, come to contradict themselves or, again, come to criticize themselves. The solution to the tensions that beset societies, that is, is an advance that incorporates and yet transfigures its original, conflicted forms. This is why all dialectic has a kind of enigmatic, riddling character, for forms of social life are all at once burdened with their past and yet pregnant with their future. Marx uses this metaphor of that reality is "pregnant with the future" in April, 1856 in a speech he gave in London on the anniversary of the "Peoples' Paper", but of course the original use of this metaphor is by Socrates in Plato's Symposium and Theaetetus-for Socrates the philosopher is a midwife whose task it is to help others "give birth in beauty." And so too Marx, in Capital I, "Force is the midwife of every old society pregnant with a new one. It is itself an economic power."

I will like to explore human rights in the light this enigmatic, dialectical form of argument, and do so by means of the struggle of traditional peoples and communities for their socio-environmental rights in Brazil. What does it mean when campesinos organize themselves, join the MST or other unions of rural workers, occupy private property and thereby re-appropriate the means of production? What does it mean when they create an "illegal" encampment and later a legalized "settlement", and provide for themselves the means of subsistence, education and health care? Indeed, 
what does it mean when an indigenous people fights to control its land in the midst of threats from speculators and invaders, seeks to protect the environment from pollution and industrial devastation, and seeks to have these claims recognized by nation-states and the international community? What these traditional peoples and communities are doing is not only seeking a right to their own self-determination, but giving birth to a new chapter in the history of their own self-determination and, indeed, human freedom itself. Herein, self-determination is not a characteristic of an abstract citizen or human being, but the concrete self-determination of an otherwise marginalized or oppressed people or community in the context of a hegemonic society. This includes, of course, its special and intimate relationship with nature. Concrete self-determination means not only laying a claim to the intellectual rights of freedom of expression, association, education and cultural integrity, but also to the material rights to have a sustainable relationship to the land and resources necessary to the community. This means, in other words, that the projects of self-determination of traditional peoples and communities are projects of socio-environmental rights.

Clearly, then, the struggles of traditional peoples and communities in particular as well as the concept of socio-environmental rights in general articulate aspirations to emancipatory self-determination. But emancipatory self-determination is freedom, and freedom is the category sine qua non of the Enlightenment. In fact, I would like to elaborate five ways that the struggles of traditional peoples and communities draw upon the traditional concepts of Enlightenment discourse, all of which are also evoked equally by traditional notions of individual rights. If freedom is the first and foremost Enlightenment principle, these projects are also, second, projects of equality. This is because socio-environmental rights can be recognized equally of MST settlements, aboriginal peoples, ribeirinhos, quilombolas, and any other community that would lay a claim to them. Or again, when an indigenous people makes a claim for the recognition of socio-environmental rights this implies the demand for the recognition of the same right made by some other community or people. This, then, also implies a further and third Enlightenment principle: universality, for any and all communities and peoples have the right to exercise self-determination in the context of a hegemonic society. Moreover, since this struggle seeks the institutional recognition of these rights by the state, yet another key Enlightenment premise is also evoked. That is, fourth, it is the proper role of the state to proclaim, uphold and enforce rights within its own constituency - the rights of citizens. Fifth, and finally, even though it is the very 
logic of these rights to be recognized by particular national states they not merely citizenship rights pertaining to membership in this or that state, but human rights which must be recognized by the cosmopolitan, international polity. This is, of course, precisely what happened with the Convention of Indigenous and Tribal Peoples of 1989, promulgated by the International Labour Organization of the United Nations and United Nations Declaration of the Rights of Indigenous Peoples of 2007.

But this is only one half of our enigma, for the struggles of traditional peoples and communities not only evokes traditional principles of human rights but also extends them in quite radical new directions. In order to help make sense of this I will briefly put Jacques Rancière's notion of "dissensus" to work. If there is a "consensus" about the character of individual human rights in the hegemonic society, the activism of traditional peoples and communities ruptures this consensus, interjecting a dissensus and activating the political process. This is because, as Rancière says, "(F)redo and equality are not predicates belonging to definite subjects. Political predicates are open predicates: they open up a dispute about what they exactly entail and whom they concern in which cases." ${ }^{\prime 7}$ In other words, the principles of Enlightenment freedomliberty, equality, universality, citizenship right and human right — are capable not only of grounding individual rights that justify and enable capitalism, but also of inaugurating an open political dissensus in which people enlarge upon, transform or develop the notions of freedom, equality and universality. Let us look at how traditional peoples and communities in Brazil have opened up this kind of dissensus.

First, traditional peoples and communities have insisted not just upon individual but collective rights. If individual rights occlude and enable the domination of some collectivities over others - the domination of one economic class over others in Marx's case-socio-environmental rights insist upon the rights of marginalized and exploited collectivities, and achieves their rights not qua individuals, but qua communities. An individual right is considered just in so far as it protects the right of each person to posit him or herself as an autonomous end, to use Kantian vocabulary, and thus to think and speak for him or herself and to not be reduced to any dominant norms or beliefs. In this sense, individual rights are necessary conditions for the possibility of human self-determination. Collective rights do the same kind of thing. If individual rights ensure that the freedom of persons means that they cannot be reduced to dominant modes of thought or action, collective rights ensure that the selfdetermination of collectivities are not reducible to the hegemonic society in which they 
find themselves. Collective, socio-environmental rights certainly evoke the traditional principles of Enlightenment freedom, but do so in a way that dramatically transforms them.

Second, socio-environmental rights weaken rather than strengthen capitalism. As Marx argued, capitalism knows no boundaries or borders. It transgresses every limit in its insatiable need for yet more resources, yet more cheap labour, yet more markets. Moreover, Marx is clear that this is not just because of greed and the general moral failure of capitalism's practitioners. Competition requires that capitalist enterprises expand infinitely or else lose to their competitors. Socioenvironmental rights create barriers to this expansion, protecting islands of communal life in which not only are economies sustainable with respect to nature, but are a means to the end of the community. As we have already seen, settlements of the MST strive to create socialist values by sharing resources and labour in various ways and by building cooperatives all the way from modest marketing coops to full production coops. Since in many of these cases traditional peoples and communities have common property of the means of production, do not exploit labour, and have a sustainable relationship with nature they also embody very substantive forms of resistance. Here, the rights discourse of the Enlightenment are evoked and elaborated upon in a manner that, once again, limits and curtails capitalism rather than enabling it.

\section{THE HISTORICAL AND YET OBJECTIVE VALIDITY OF HUMAN RIGHTS}

In this final section of this paper, I would like to articulate how these historically achieved human rights have a kind of universal and objective validity despite the particularity of when and where they emerge. The key to the argument, to put it most simply and directly, is that humanity learns about the necessary conditions of its own freedom in and through struggle. Let us begin with individual rights and then consider collective, socio-environmental rights. I will defend the universality of both. Usually arguments for the universality of human rights are anti-historical—rights, their philosophical defenders seem to think, must be shown to arise from permanent, "natural" properties of human beings. This is a tall task. The dialectical argument I present here, on the other hand, attempts to show instead that human freedom is 
developed in history and elaborates itself in time into more and more sophisticated forms.

The single most important philosophical event in this self-development of right, in the West at least, is the skepticism of Socrates. Plato taught us that the human mind could doubt any belief, custom, law, opinion or assertion. In so doing the individual mind becomes arbiter of truth, determining on its own what is true and false. This means, as Kant showed most clearly, that human beings necessarily posit themselves as ends in themselves. What Kant called the kingdom of ends, therefore, extends mutual recognition, to use Hegel's term, to all human beings as free. The key to all individual right, then, is Kant's categorical imperative to treat other people as ends and never simply as means. Individuals are autonomous and self-determining, and the right to be respected as such merits the recognition of all others and by the state.

Moreover, this originally Socratic skepticism leads inevitably to a kind of pluralism. We see that individuals acting with integrity can reach different conclusions in and through this process of doubt. They can also pursue very different notions of the good life. This means that the public sphere is characterized by an irreducible pluralism of values and positions and that this pluralism follows directly from the nature of freedom itself. The rights to freedom of speech and thought, to association and inquiry, to a free press, and to academic freedom are all premised on something like Socratic skepticism (and its Kantian legacy). Yet, my allusions to history indicate that freedom develops slowly over time, in the long historical struggle of humanity not to discover some heretofore hidden natural right, but to create and elaborate its own freedom. Moreover, this power of freedom, based on the capacity to doubt, is undoubtedly universal. A key stage in this process of self-learning and self-understanding is the moment when we recognize the importance of these facets of freedom to such an extent that we determine that they require institutionalized recognition and protection, such as the way in which the Nazi Holocaust led to the promulgation of the United Nations Charter of Human Rights in 1948.

Let me make one last point about the historicity of individual right: once it is achieved, it is extremely hard to undo. There are two reasons for this. Logically, first, to doubt the veracity of individual right requires exercising precisely the sceptical capacities that made individual rights necessary in the first place. It is therefore a contradiction to doubt individual right. Second, empirically, an increasingly cosmopolitan world juxtaposes dramatically different and contested world-views and 
metaphysical positions, undermining all of their authority. One must either fight to preserve the metaphysical supremacy of one's own stance or compromise it in some gesture of mutual recognition and pluralism. But any such compromise always transforms what was once a metaphysical or absolute position into a mediated or relative one. This kind of transition presupposes a version of the skeptical detachment that Socrates inaugurates. The philosopher Charles Taylor thus says that there is a dialectical "ratchet effect" in history. ${ }^{8}$ Rights, once achieved, take on an objective stability, preventing them from slipping backwards but at the same time making possible further elaborations and developments. Taylor's point dovetails with Rancière's argument cited above, for both are dialectical arguments. This historically achieved yet objective universality of individual rights, in other words, is precisely that which provides the basis for the achievement of collective and socio-environmental rights, to which we now turn.

In the argument that justifies individual rights the key premise was the irreducible way in which human singular freedom presupposes the skeptical powers of the mind and the self-determination of the individual. One's individual identity cannot simply be reduced to any determinate cultural, ethnic, legal, religious (etc) belief. The individual, in other words, has the right to determine his or her own identity in a manner irreducible to the form of other identities, especially hegemonic ones. Collective rights, have exactly the same form, except that they are predicated on a collective rather than individual claim to self-determination. So again, like individual right, a collective right insists that a particular community not be reduced to the identity of any other community, especially not a hegemonic one. Of course collective right needs to be asserted precisely when the self-determination of a community is under threat, something that is manifestly true of all of those included within the notion of traditional peoples and communities. In this case, however, material rights are all the more important. This is because the mode of material production of these communities is not only a necessary condition of their survival, but also because the forms of culture they defend are themselves replete with the kinds of meaningfulness that arises from these modes of production. By extension, the right to land (for aboriginal peoples, agrarian reform settlements, Quilombos, etc.) is not merely a material condition for selfdetermination in some technical or instrumental sense, but is woven into the fabric of cultural self-determination itself. This often takes the form of an assertion of a deep and organic connection to nature among traditional peoples and communities, and a 
concomitant refusal to be reduced to the alienated and instrumental attitude toward nature that predominates in capitalism. This sums up well the philosophical positions embodied in the notion of socio-environmental rights.

\section{CONCLUSION}

I would now like to draw this paper to a close. Dialectical philosophy, of the sort practiced by Marx, allows us to synthesize two poles of argument normally taken by liberal philosophers to be mutually exclusive: the universality of rights versus the historicity of rights. Dialectics allows us to see the reason in history: freedom is not some natural quality revealed by pulling aside the veils of illusion, but is created and elaborated in and through human striving and struggle. If individual right is premised first and foremost on the singular person's capacity to doubt and assert him or herself as a unique point of reference for self-determination, the freedom of collectivities demonstrates that individuals are always, despite their singularity, committed to particular ways of being human: this form of culture rather than that, this religious viewpoint rather than that, and so on. These discrete cultural forms are themselves modes of self-determination, and thus deserve the same kind of recognition in right as does the freedom of the individual. The struggle of traditional peoples and communities in Brazil embodies this kind of historical self-determination and, moreover, does so in a way that also sheds light on the destructive and instrumental attitude toward nature practiced by the hegemonic society. The notion of socio-environmental right is thus itself a key moment in the elaboration of humanity's ongoing project of selfdetermination. More generally, individual, collective and socio-economic rights are each necessary but, on their own, insufficient conditions for self-determination. Does this mean that, together, they form the sufficient conditions of self-determination? Only history can answer that question. Meanwhile, acting in solidarity with traditional peoples and communities, we participate in the co-creation of human freedom.

\section{BIBLIOGRAPHY}

Kamenka, Eugene, Ed., The Portable Karl Marx, London: Penguin, 1983.

Marx, Karl, Capital I, Trans., Samuel Moore and Edward Aveling, New York: International Publishers, 1967. 
Speech at Anniversary of Peoples' Paper. Retrieved from

Disponível em <https://www.marxists.org/archive/marx/works/1856/04/14.htm>.

Samuel Moyn, The Last Utopia Human Rights in History, (Cambridge : Harvard University Press, 2010).

Jacques Rancière, "Who is the Subject of the Rights of Man?", South Atlantic Quarterly, 103 (2/3), 303.

${ }^{1}$ Marx's most systematic argument for exploitation is in Capital I, Part III, Chapters VII-IX.

${ }^{2}$ Samuel Moyn, The Last Utopia Human Rights in History, (Cambridge : Harvard University Press, 2010).

${ }^{3}$ Karl Marx, Economic and Philosophic Manuscripts of 1844, cited from Eugene Kamenka, Ed., The Portable Karl Marx, London: Penguin, 1983), 150.

${ }^{4}$ Karl Marx, Economic and Philosophic Manuscripts of 1844, cited from Eugene Kamenka, Ed., The Portable Karl Marx, London: Penguin, 1983), 150.

5 "In our days, everything seems pregnant with its contrary." (1969) Speech at Anniversary of Peoples' Paper. Retrieved from https://www.marxists.org/archive/marx/works/1856/04/14.htm.

${ }^{6}$ Karl Marx, Capital I, Trans., Samuel Moore and Edward Aveling, (New York : International Publishers, 1967), 751.

${ }^{7}$ Jacques Rancière, “Who is the Subject of the Rights of Man?", South Atlantic Quarterly, 103 $(2 / 3), 303$.

${ }^{8}$ For example, The Secular Age, 273. 